\title{
Promoting SPELL ELC Using a Marketing Booklet
}

\author{
Arniescza Ratna Hayu Budi Utomo \\ English Department, Faculty of Languages and Literature, Petra Christian University, \\ Siwalankerto 1211-131, Surabaya 60236, INDONESIA \\ Arniesczautomo@gmail.com
}

\begin{abstract}
SPELL ELC (Special Programs for English Language \& Literacy English Language \& Communication) is an English institution located in Pondok Mutiara blok MEA 8, Sidoarjo. This company claims themselves as an English school. It provides three kinds of English education programs which are English for Children's Programs, English for Academic Programs, and English for Business Programs. Those programs focus on the kids to adults students based on their needs. However, there are only few people know these programs. It means that they need to be promoted in order to make this institution well-known by others. Therefore, creating a marketing booklet is the best solution for SPELL ELC since the booklet provides complete information about each programs to the potential customers. The content of marketing booklet consists of company's overview, products' description, and contact information. In the products description, the information is more emphasized so that the customer can read them clearly.
\end{abstract}

Key words: promotion tool, marketing strategy, marketing booklet

\section{INTRODUCTION}

Brand awareness is important for every company. It helps company to make the customers know more about the products of the company. To make people know the programs, it is needed that the booklet written in enough information. It also helps company to get the people's attention. SPELL ELC also one of company that needs to make the customers know the products. To make SPELL ELC's customers know the programs, they need a promotion tool which is creating a new marketing booklet.

SPELL ELC was esablished in 2001. It also has two locations which are in Pondok Mutiara blok MEA 8, Sidoarjo and Pondok Asri A/3, Bangkalan, Madura. This instution has three kinds of English programs such as Children's English, Academic English, and Business English Programs. Through these programs, it can be concluded that the students can be from children to adults. During in my internship, I found three problems that needed to be solved. They are it needed direct feedback, it needed to be promoted by the online stuffs, and it needed a promotion stuff; a booklet.

First of all, it needed a direct feedback. Based on the information I got from the manager of SPELL ELC. She said that only some of the customers gave the feedback. The rest did not give the feedback after the term is ended. I think this was one of their problems. However, the manager also told me that this problem already had the solution.the solution was a staffer made a questionnaire at "Google form" for the feedback. It is usually distributed to the customers after the term ends. Therefore, the customers could fill the questionnaire and give the suggestion to SPELL ELC.

The second problem was the programs of this company needed to be promoted on the internet which is called digital promotion. Digital promotion is a product or a program which is promoted through the online sources such as Whats App, Instagram, FaceBook, Line, and stuffs. The reason behind needed more promotion on internet stuffs was they did not have time to spend their time on opening, editing, and uploading the programs' information or events. However, this problem had been solved by giving a turn to open, edit, and upload the events and information about each program.

The last problem was this company needed a marketing booklet as a promotion tool in order to promote their programs. Before deciding to make a booklet as my project, the director of SPELL ELC asked to make a video promotion. After searching the root of lack of promotion problem, he decided to make a booklet as a promotion tool. He said that the company needs to make a new booklet. Through the marketing booklet, people would know more about the products from this company. 
From these three problems, I would like to solve the three problems which had been asked by the director since he knew the root of the problem. Making a booklet is a demand for SPELL ELC. What I meant by a demand for SPELL ELC is making a new booklet will help people, visitors and loyal customers to know the products of this company. In addition, the old booklet needs to be upgraded. What to be upgraded is needing to add new program in the contents of the booklet. The contents of old booklet only has some products mentioned while there is a new program named ILU (Independent Learning Unit) from SPELL ELC that is not mentioned in the old booklet. During creating the new marketing booklet, the manager of SPELL ELC also has a plan to remake the brochures in terms of making new design of brochures since the design of the brochures is old. Along in making a new booklet, SPELL ELC will also renew the brochures.

Creating a new marketing booklet, there are three benefits that can be got for the company. First of all, the marketing booklet gives a lot of information of each program of company. The booklet will consist of the details of each program. The detail will be typed in every program of the company in the a marketing booklet. Inside the booklet, it will be included the information of the each program such as Children's English programs, Academic English programs, and Business English programs and the teachers \& staffers.

Secondly, it helps SPELL ELC to increase the income. Increasing income is also one of the goals for every company. Increasing income helps the development of the company itself and the prosperous for its owners, staffers and teachers. This booklet also helps SPELL ELC to increase their income. By reading the booklet, the customers will not be confused since the all information of SPELL ELC and its products are inside. Therefore, they do not worry to decide to make their children or theirself to join the programs.

Lastly, it helps the company to increase the brand awareness. Increasing brand awareness is important. By increasing brand awareness the people will know and recognise its company and the products. Next, the brand awarenes can affect to the increasing the customers of this company. Therefore, by using the marketing booklet, people can know the brand of its company and programs. To show the brand awareness in the booklet, I type some detail information accurately, therefore customers will not worry about the program that will be used in the future.

In order to create a new booklet, I use some theories to assist it. Marketing according to Kotler (2006, p. 5) is a process of selling and buying goods among the people. It has two goals which attract new customers by giving the promising value and it keeps and grows the current customers by making them happy after using or buying our products. Marketing strategy according to Tiwary (2003, p. 167) is formulated according to psychological behaviour of customers which is influenced by social family, economic, cultural, political and geographical environement. To simplify this, the marketing strategy is a strategy that is formulated based on the customers behaviour in order to reach the goals of the company.

Promotion tools are the most important thing for every company. Promotion based on Tiwary (2003, p. 168) is a psychological approach which touches the hearts and the minds of the customers in order to buy the products from the company. On the other hand, tool is an item that is used for a specific aim. It can be a physical object or technical object. It can be concluded that promotion tool is a psychological approach which can be physical or technical object that can touch the heart and mind of the customers to buythe products. The customer in this chapter means the real person who buys or purchases the products influenced by other customers (Tiwary, 2003).

Making a marketing booklet is one of the marketing strategies. Before defining the definition of marketing booklet, it is important to know the meaning of a booklet. A booklet according to Bly $(2009$, p. 37) is a small book designed and made in order to give information to the customers about the products, services, and the company. It also ranges from eight to sixteen pages or more (Waters, 2008). A booklet can also be called a catalog. Catalog is a list of items that are usually used for the sale or for some purposes (Julia, 2017). It concludes that a booklet is a small book which may range more pages in order to educate the customers about the products, services and the information of the company itself. 
Not only those principles, there are also principles in making a marketing booklet based on Adkins (1994, Pp. 6-20) first, it must have enough information typed, second, it must use interesting pictures, logos, colours, circle, square, and symbols, third, it is important to find the suitable paper for booklet, fourth, to select the media-printer-service is important, last, finding the suitable folding and shape of booklet is also important. In addition, based on Messaris's theory about pictures (1997, p.3) said that pictures can create the kinds of visual information which our eyes and brains can see as the real situation. Next, according to Drew $(2009$, p. 6), it is said that color not only affects the readability and legibility of text, but also associated behavioral effects. It can be concluded that adding pictures and choosing colors are important in creating a marketing booklet.

\section{METHOD}

The approval from the owner of the business in making this project is the most important thing. Here are the flow of asking the approval in creating a booklet. After having done the thesis defence, I got to do some revisions. Then, I started to write the company proposal for SPELL ELC with applying the design that would be used for the marketing booklet. While doing the proposal, I asked to the manager about the price that would be included in making the marketing booklet. In the proposal I approved some money which is used for making a new marketing booklet. I proposed 3.000.000 rupiahs for making a booklet.

That price in making marketing booklet included the pdf, corel draw file, and print out file. 3.000.000 rupiahs was enough in making the booklet since the designer of the marketing booklet was the designer that SPELL ELC always calls. For instance, SPELL ELC asked her to make the design of company's logo and some brochures in the past. Next, I sent the proposal and discussed the details design in the marketing booklet for the company with the owner, Mr. Jusuf I. Ibrahim and the manager, Ms. Shirley Yanis of SPELL ELC.

In that discussion, I showed the ideas that would be used in making the booklet interesting. Then, the owner of SPELL ELC gave me some advice about the contents and gave me access to talk with his designer, Ms. Yulia, an alumnus of Visual Communication Design from PETRA. While I talked the idea of the marketing booklet, the owner also had an idea to remake new design of brochures for SPELL ELC. The brochures would be done after the designer finished the booklet.

\section{FINDINGS AND DISCUSSION}

This part contains of the description of the tool, its users, ans its use. The tool that I used for solving this company's problem was making a marketing booklet. Marketing booklet is the most important tool for this company to promote their programs since their main strategy in promoting the products is promoting programs directly to customers. The message of creating marketing booklet was to make customers know and understand the programs which SPELL ELC has. This message can be known directly by the customers after they have read the marketing booklet. It also includes the USP of the company that helps customers to know the programs.

According to the theory of Adkins (1994, Pp. 6-20), using some pictures attract the readers' attention. Therefore I use some pictures that can attract the reader to read the booklet. The pictures are taken from the activities of the students. These examples of activities are what students do during the class, what students do while in the course environment, and the activities while the students are together. Through the pictures which can attract the readers, I believe that this booklet will help SPELL ELC to increase the students. Through the pictures which can attract the readers, I believe that this booklet will help SPELL ELC to increase the students. These are the examples of pictures I use in making a marketing booklet: 


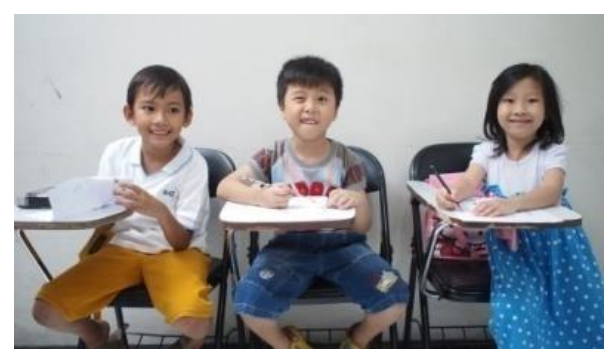

Figure 1

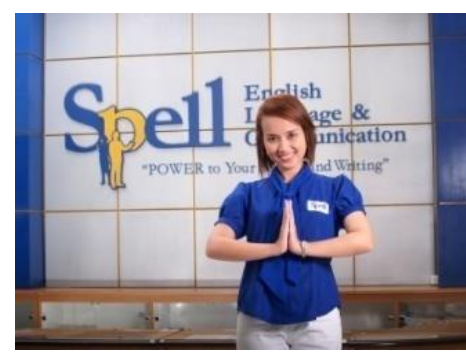

Figure 2

In the booklet figure 1 presents as the children programs with the most popular program of SPELL ELC, Regular program. Next, on figure 2 is the picture presents the welcoming the customers of SPELL ELC.

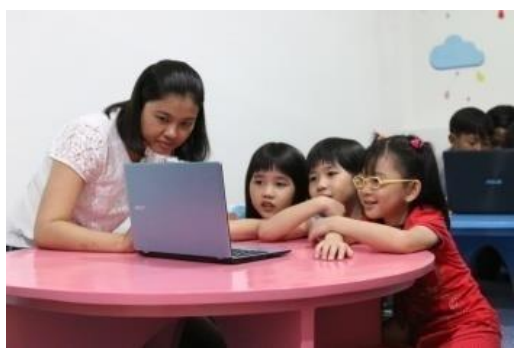

Figure 3

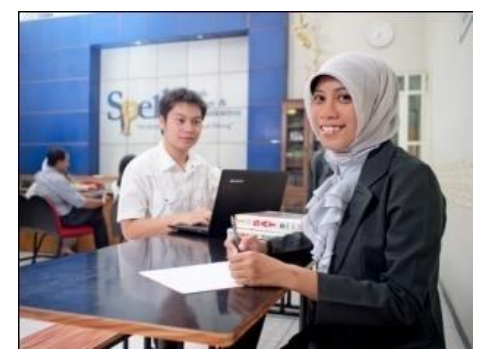

Figure 4

Next, figure 3 is representing the new program of SPELL ELC named Independent Learning Unit (ILU ). Next to the figure 3, there is figure 4 which represents the business program to the customers.

Moreover, according to Drew $(2009$, p. 6) color does not only affect the readability and legibility of text, but also associated behavioral effects. It means that colors are very important which can make the booklet readable and affect the behavioral of the readers. This is the example of colors that I use in making a marketing booklet:

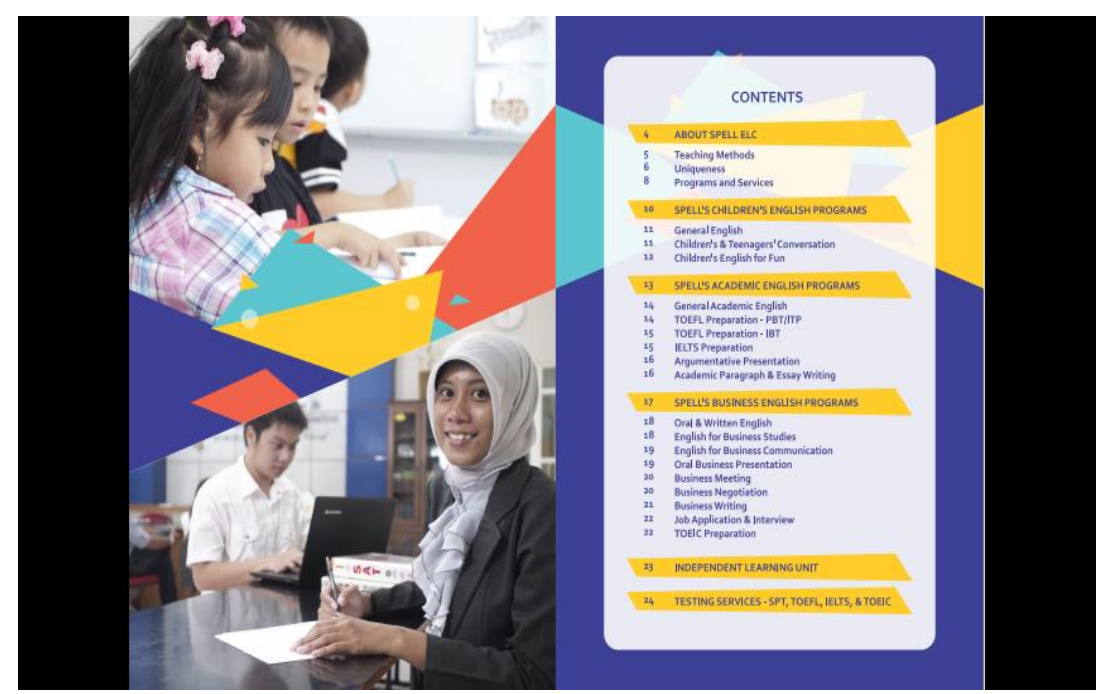

Figure 5 
Next, the overview of the company is included in the contents of a marketing booklet. An overview of the company is the most important thing to add in the company booklet since this booklet depends on the company. Last, the additional content is the data of the teachers and the staffers. According to the theory above, creating a booklet depends on the purpose of the company. Since the purpose of creating this marketing booklet is to increase the students of SPELL ELC, it is useful if there are the data of the teachers and staff officers who directly meet and talk to students.

Finally, I made two marketing booklets which were divided into two languages. Those languages are English and Indonesia. First of all, the reason of using Bahasa Indonesia in the booklet is because the main target market of SPELL ELC is Indonesian people. Since the target market of this company is Indonesian people, it is better to include Bahasa Indonesia. Secondly, the reason using English is because SPELL ELC is an English course, in my opinion, it is better to include English for second language on contents. Based on these reasons, I think it helps SPELL ELC if they suddenly have foreign students or visitors.

This marketing booklet is expected to be used for the staff officers to promote and introduce the company's programs/products based on the contents. The main customers can also be the users of this marketing booklet since they are the main customers. Because of this booklet has two versions of languages, the users can be Indonesian and foreign people. This booklet is expected which the contents are understood and known by its readers.

Last but not least, The use of this marketing booklet is to make the readers know and understand the programs SPELL ELC provides. Besides making them know and understand the products, it is also expected to the customers that they can be attracted to join the programs after reading the booklet. What makes them attracted is they can read all detail information; see the activities through the pictures and the attractive design. This booklet will talk about the programs they need.

\section{CONCLUSION}

For my Business Communication Final Project, I decided to make a marketing booklet for SPELL ELC, the company where I did internship. There are three main problems that I found during my internship. The problems were they needed the direct feedback from its regular customers, they needed to be promoted through the internet, digital promotion, and they needed to create a promotion tool, a marketing booklet in order to make them easier to promote the programs.

The reason behind making this marketing booklet is to promote this company to the customers around or outside Sidoarjo. Before choosing to make the booklet, I had an idea to make the video promotion since it is easy to be used and shared, however it got changed to the marketing booklet by the owner since they only need the marketing booklet instead of creating video promotion. In addition, recreating new marketing booklet helps the company to increase the brand awareness of SPELL ELC so that their programs and its company will be well-known by others.

Next, there are benefits in creating a new marketing booklet. First of all, it helps company to show their programs' information to the people easily. It can be spread through the potential customers who can also help customers of the company to know and recognise the programs. Secondly, it can help increase the brand awareness of this company which it can be used by spreading the information through the book. As a result, this company can be known by their customers. Lastly, since people know the programs and the company, it is easy for them to increase the students.

\section{REFERENCES}

Adkins, V. (1994). Creating Brochures \& Booklet. Cincinnati, Ohio: North Ligh Books

B ly, R. (2009). 88 Money-Making Writing Jobs. Naverville, Illinois: Sourcebook.inc

Julia, C. (2017). Types of Catalogs. Retrieved from: https://bizfluent.com/facts-5315048-typescatalogs.html

Kotler, P., \& Armstrong, G. (2006). Principles of marketing. New Jersey, United States: Pearson Prentice Hall

Messaris, P. (1997). Visual Persuasion: The Role of Images in Advertising.Thousand oaks, California: SAGE Publications 
Tiwary, S. (2003). Marketing Promotion Policies in India. New Delhi, India: Size-Demy

Waters, M. (2008). Easy Business for Women with Little or No Money. Bloomington, Indiana: Author Solutions 